\title{
Mutations in the STAT5A Gene Are Associated with Embryonic Survival and Milk Composition in Cattle
}

\author{
H. Khatib, ${ }^{\star 1}$ R. L. Monson, $†$ V. Schutzkus, ${ }^{\star}$ D. M. Kohl, $†$ G. J. M. Rosa, ${ }^{\star}$ and J. J. Rutledge† \\ *Department of Dairy Science, and \\ †Department of Animal Sciences, University of Wisconsin-Madison, Madison 53706
}

\begin{abstract}
The objective of this study was to investigate the association of the signal transducer and activator of transcription 5A (STAT5A) gene with fertilization rate, embryonic survival, and milk production and composition in cattle. The STAT proteins are transcription factors that are specifically activated to regulate gene transcription when cells encounter cytokines and growth factors. The STAT5A gene is a member of the interferon- $\tau$ (IFN- $\tau$ ) and placental lactogen (PL) signaling pathway, which is involved in both milk production and initiation of pregnancy. Using the DNA-pooling sequencing approach, a total of 12 single nucleotide polymorphisms (SNP) were identified, 1 exonic and 11 intronic. For the study of association of these SNP with embryonic survival, 1,551 embryos were produced in vitro from 160 cows and 3 sires. Significant associations with embryonic survival were found for 7,5 , and 2 SNP for embryos produced from sires 1,2 , and 3 respectively. The association of fertilization rate with STAT5A polymorphisms was evaluated in more than 2,300 oocytes. Significant associations were found for 6,2 , and 2 SNP for sires 1, 2, and 3 respectively. For sire 1, 5 SNP showed significant associations with both embryonic survival and fertilization rate compared with 1 SNP for sires 2 and 3. To determine if embryonic losses had occurred before the blastocyst stage, 145 of the surviving embryos were harvested at $\mathrm{d} 7$ of development and genotyped for the single exonic SNP12195. A significant segregation distortion was observed between oocytes produced from 2 sires carrying the same genotype. Thus, it is most likely that STAT5A is associated with 2 mechanisms of embryo death. One is a prefertilization mechanism involving sperm factors that cause low fertilization rate. The second is a postfertilization mechanism that causes incompatibility between the male pronucleus and the oocyte, which in turn leads to death
\end{abstract}

Received September 5, 2007.

Accepted October 2, 2007.

${ }^{1}$ Corresponding author: hkhatib@wisc.edu of the embryo before the blastocyst stage. Association testing of SNP12195 (exon 8) and SNP14217 (intron 9) with milk composition revealed that allele $G$ of SNP12195 was associated with a decrease in both protein and fat percentages. However, SNP14217 in intron 9 showed no significant association with milk production or health traits. The G allele of SNP12195 was also associated with low embryonic survival, making this SNP an attractive candidate for progeny testing programs in dairy cattle.

Key words: STAT5A, embryonic survival, lethal mutation, milk composition

\section{INTRODUCTION}

The signal transducer and activator (STAT) proteins are known to play an important role in cytokine signaling pathways. The STAT proteins are transcription factors that are specifically activated to regulate gene transcription when cells encounter cytokines and growth factors. Hence, they act as signal transducers in the cytoplasm and transcription activators in the nucleus (Kisseleva et al., 2002). In mammals, the STAT proteins comprise a family of 7 structurally and functionally related proteins: STAT1, STAT2, STAT3, STAT4, STAT5A, STAT5B, and STAT6 (Darnell, 1997). The 7 mammalian STAT proteins range in size from 750 to 850 AA. The chromosomal distribution of these STAT, as well as the identification of STAT proteins in more primitive eukaryotes, suggest that this family arose from a single primordial gene (Chen et al., 1998). In addition, STAT share a number of structurally and functionally conserved domains.

The STAT5A protein is also known as a mammary gland factor that was initially identified in that tissue as a regulator of milk protein gene expression (Watson, 2001); and is a member of the interferon- $\tau(\mathbf{I F N}-\tau)$ and placental lactogen (PL) signaling pathway. It is involved in signal transduction within a variety of cells, including the uterus and mammary epithelial cells. The uterus is exposed to IFN- $\tau$ and PL, as well as many others hormones including estrogen, progesterone, and placental growth hormone. The PL stimulates the for- 
mation of STAT5 homodimers, which in turn induce the transcription of the bovine uterine milk protein $(U T M P)$ and osteopontin $(O P N)$ genes (Spencer and Bazer, 2002, 2004; Stewart et al., 2002). In previous studies, we showed that the UTMP (Khatib et al., 2007a) and $O P N$ (Leonard et al., 2005; Khatib et al., 2007b) genes have surprisingly strong effects on milk production and health traits in cattle. Furthermore, we showed that STAT1-also a member of the IFN- $\tau$ and PL signal transduction pathway-is associated with milk composition and health traits (Cobanoglu et al., 2006).

Studies in mouse have shown that Stat5a is involved in both milk production and fertility; and Stat 5 knockout female mice fail to lactate (Miyoshi et al., 2001). Also, it has been shown that disruption of Stat5 leads to infertility in females as a result of small-sized or absent corpora lutea (Teglund et al., 1998). Because the primary source of progesterone is the corpora lutea of the ovary, lack of development of corpora lutea would have significant effects on the establishment of pregnancy.

In this study, STAT5A was chosen as a candidate gene because it is a member of the IFN- $\tau$ and PL signal transduction pathway, which is very important in both milk production and initiation of pregnancy. In addition, other genes in this pathway have been found to be associated with milk production and health traits. The objective of this study was to investigate if STAT5A variants are associated with milk production and reproduction traits in dairy cattle using association tests and in vitro fertilization.

\section{MATERIALS AND METHODS}

\section{Polymorphism Identification}

A total of 160 ovaries were collected from 160 Holstein cows obtained from a local abattoir in Wisconsin. Genomic DNA was extracted from ovaries by grinding 30 to $100 \mathrm{mg}$ from each ovary using the AquaPure Genomic DNA kit (BioRad, Hercules, CA). To detect single nucleotide polymorphisms (SNP) in the STAT5A gene (GenBank accession number NC_007317), DNA pools were constructed from 50 different ovary samples and amplified with the primers listed in Table 1. Primers in STAT5A were designed to amplify regularly spaced exonic and intronic regions of the gene, with the exception of a 2,619-bp stretch extending from intron 5 to intron 7. In this region, the STAT5A and STAT5B genes share about $99.43 \%$ of their sequence, making it nearly impossible to design STAT5A-specific primers. The PCR products of the pooled DNA samples were sequenced using BigDye terminator (Applied Biosystems, Foster City, $\mathrm{CA}$ ), and SNP were identified by visually inspecting sequence traces. For individual genotyping, ovary DNA was sequenced.

\section{In Vitro Fertilization and Survival Rate Assessment}

Ovaries were collected from a local abattoir and immediately used in the in vitro fertilization (IVF) experiments. Oocytes were aspirated from antral follicles $(>2$ to $6 \mathrm{~mm}$ ) and selected for study if a compact cumulus of several cell layers was present. Oocytes were processed in Tyrode's albumin lactate pyruvate (TALP)HEPES with $0.22 \mathrm{~m} M$ sodium pyruvate, $25 \mu \mathrm{g} / \mathrm{mL}$ gentamicin sulfate, and $3 \mathrm{mg} / \mathrm{mL} \mathrm{BSA}$, and immediately incubated for 20 to $24 \mathrm{~h}$ in $50-\mu \mathrm{L}$ drops of maturation medium that had been equilibrated in $5 \% \mathrm{CO}_{2}$ in air at $39^{\circ} \mathrm{C}$ and high humidity. Maturation medium consisted of M199 with Earle's salts supplemented with bovine LH and FSH (3 $\mu \mathrm{g} / \mathrm{mL}$ each) from Sioux Biochemical (Sioux Center, IA), $0.22 \mathrm{~m} M$ sodium pyruvate, $25 \mu \mathrm{g} / \mathrm{mL}$ gentamicin sulfate, and $10 \%$ fetal bovine serum. On d 2, oocytes were washed 3 times in TALPHEPES and placed up to 10 oocytes per $44-\mu \mathrm{L}$ microdrop (overlaid with mineral oil) of IVF-TALP (Biowhittaker, Walkersburg, MD) supplemented with $0.22 \mathrm{mM}$ sodium pyruvate, $25 \mu \mathrm{g} / \mathrm{mL}$ gentamicin sulfate, and 6 $\mathrm{mg} / \mathrm{mL}$ essentially fatty acid-free BSA.

Oocytes were fertilized with frozen-thawed Percollseparated (Sigma, St. Louis, MO) bull semen after being adjusted to a final concentration of 1 million sperm $/ \mathrm{mL}$. Each microdrop received $2.0 \mu \mathrm{g} / \mathrm{mL}$ heparin to help induce capacitation, as well as hypotaurine, penicillamine, and epinephrine to maintain sperm membrane integrity and motility. Oocytes and sperm were coincubated for a period of 18 to $24 \mathrm{~h}$. After the fertilization period, putative zygotes were stripped of their cumulus cells by vortexing for $3 \mathrm{~min}$ and washed 3 times in TALP-HEPES before being placed into $50-\mu \mathrm{L}$ microdrops (overlaid with mineral oil) of synthetic oviductal fluid (Biowhittaker) supplemented with $0.22 \mathrm{~m} M$ sodium pyruvate, $25 \mu \mathrm{g} / \mathrm{mL}$ gentamicin sulfate, and $8 \mathrm{mg} /$ mL essentially fatty acid-free BSA. A total of 160 cows and 3 sires were used in the IVF experiment.

Survival rate of embryos (number of viable embryos out of total cultured) was evaluated at d 7 of development $($ where fertilization $=d 0$ ). Embryos were preserved in RNALater RNA stabilization reagent (Qiagen, Valencia, CA) to avoid RNA degradation. The proportion of unfertilized ova (UFO) was calculated as the number of unsuccessful fertilizations out of the total embryos cultured. Survival and fertilization rates were assessed by one technician and were done under the same environmental conditions to minimize biased results. 
KHATIB ET AL.

Table 1. Primer sequences, locations, and amplification product sizes

\begin{tabular}{|c|c|c|c|}
\hline Primer & Location & Sequence & Product size (bp) \\
\hline $\mathrm{AF} 1$ & Intron 1 & GAGAGAGGGAGTGTCTTGTCTC & 831 \\
\hline AR1 & Intron 2 & GACTCCCATTTCCCTGTTCC & \\
\hline AF2 & Intron 2 & GGAACAGGGAAATGGGAGTC & 779 \\
\hline AR2 & Intron 3 & ССТТССТСССАСАСССТСАС & \\
\hline AF3 & Intron 3 & GTGAGGGTGTGGGAGGAAGG & 889 \\
\hline AR3 & Intron 4 & CACACACACTTGCCTGTGTG & \\
\hline $\mathrm{AF} 4$ & Intron 4 & CACACAGGCAAGTGTGAGAG & 881 \\
\hline AR4 & Intron 4 & GATATCAGTGTCCACCACAAG & \\
\hline AF5 & Intron 4 & CTTGTGGTGGACACTGATATC & 586 \\
\hline AR5 & Intron 4 & ACCCTCTGTGACCTGGCAAC & \\
\hline AF6 & Intron 4 & GAAGCCAGGTCACAGAGGGT & 641 \\
\hline AR6 & Intron 4 & GAAGCCAGGTCACAGAGGGT & \\
\hline AF7 & Intron 4 & GCCCAGTGCTTAAGAATCTG & 631 \\
\hline AR7 & Intron 4 & GGCAGACTCTGGTAGAAACTTC & \\
\hline AF8 & Intron 4 & GAAGTTTCTACCAGAGTCTGCC & 832 \\
\hline AR8 & Intron 5 & CCCAGGCCAAATTGCATGTTC & \\
\hline AF9 & Intron 5 & GAACATGCAATTTGGCCTGGG & 859 \\
\hline AR9 & Intron 5 & CATCAAGATAGAGCACATGCC & \\
\hline $\mathrm{AF} 10$ & Intron 5 & GGCATGTGCTCTATCTTGATG & 549 \\
\hline AR10 & Intron 5 & GCTACCTCTCTATCTATAGGAGC & \\
\hline AF11 & Intron 9 & AGCCTCTGCTCTGTAGCTGG & 649 \\
\hline AR11 & Intron 9 & TCTTGTTCCCAGCCCAAAGG & \\
\hline $\mathrm{AF} 12$ & Intron 9 & CCTTTGGGCTGGGAACAAGA & 649 \\
\hline AR12 & Intron 9 & ATCAACCTGAGAGCATCCGAG & \\
\hline $\mathrm{AF} 13$ & Intron 9 & CTCGGATGCTCTCAGGTTGAT & 971 \\
\hline AR13 & Intron 11 & GCCATTCCACAAGCCCCTTC & \\
\hline $\mathrm{AF} 14$ & Intron 11 & GAAGGGGCTTGAGGAATGGC & 889 \\
\hline AR14 & Intron 13 & AGGGGTAGAGATAGTCCCAG & \\
\hline AF15 & Intron 13 & CTGGGACTATCTCTACCCCT & 659 \\
\hline AR15 & Intron 13 & GTTAGGGCTTGTGTCCCCATC & \\
\hline AF16 & Intron 13 & GATGGGGACACAAGCCCTAAC & 730 \\
\hline AR16 & Intron 15 & GAGGATTGGAGCTGTAGGGC & \\
\hline $\mathrm{AF} 17$ & Intron 15 & GCCCTACAGCTCCAATCCTC & 809 \\
\hline AR17 & Intron 16 & CACCTGCTGACAGTCACCAG & \\
\hline AF18 & Exon 17 & GCAAGTGGTCCCGCAGTAAG & 737 \\
\hline AR18 & Intron 18 & CAGTCCCATGTGGTAGGTAC & \\
\hline AF19 & Intron 18 & GTACCTACCACATGGGACTG & 980 \\
\hline AR19 & Exon 19 & CATGTGTACATGGGCTGCCTG & \\
\hline STATF1 & Exon 8 & GAGAAGTTGGCGGAGATTATC & 840 \\
\hline STATR1 & Intron 9 & CCGTGTGTCCTCATCACCTG & \\
\hline STAT14 & Exon 8 & GAGGAGATGCTGGCTGAGGT & 440 \\
\hline STAT13 & Intron 8 & TTCAGGGGACAGGACTCTGG & \\
\hline
\end{tabular}

\section{Embryo Genotyping}

Genomic DNA was extracted from single d 7 embryos using an Ambion kit (Applied Biosystems). Embryos were genotyped for SNP12195 (G/C) in exon 8 of STAT5A using primers STATF1 and STATR1 (Table 1). Amplification was performed in a $25-\mu \mathrm{L}$ reaction volume, which included $3 \mu \mathrm{L}$ of embryo DNA, $50 \mathrm{ng}$ of each primer, $200 \mu M$ of each dNTP, $5.0 \mu \mathrm{L}$ of $5 \times$ PCR buffer (Promega, Madison, WI), and 1.5 unit of Taq DNA polymerase (Promega). The temperature cycles were as follows: $95^{\circ} \mathrm{C}$ for $5 \mathrm{~min}$, followed by 32 cycles of $94^{\circ} \mathrm{C}$ for $45 \mathrm{~s}$, touchdown annealing from $65-53^{\circ} \mathrm{C}$ for $45 \mathrm{~s}, 72^{\circ} \mathrm{C}$ for $45 \mathrm{~s}$, and a final extension at $72^{\circ} \mathrm{C}$ for $7 \mathrm{~min}$. The PCR products were amplified in a nested PCR reaction using primers STAT14 and STAT13 (Table 1). The nested PCR reaction included $1 \mu \mathrm{L}$ of PCR product, $50 \mathrm{ng}$ of each primer, $200 \mu M$ of each dNTP,
$5.0 \mu \mathrm{L}$ of $5 \times$ PCR buffer, and 1.5 unit of Taq DNA polymerase (Promega). The temperature cycles were as described for the first PCR except that the total number of cycles was set to 18. Products of the nested PCR were genotyped by sequencing and by digestion with the restriction enzyme $B s t$ EII, which distinguishes alleles C and G of SNP12195.

\section{SNP Association Testing with Fertilization and Embryonic Survival Rates}

All cows and the 3 sires used in the IVF experiment were individually genotyped for the 12 SNP by sequencing. The association between the SNP and fertilization and embryonic survival rates were studied using a GLM method (McCullagh and Nelder, 1989) for proportion data, using the binomial distribution and the logit link function. First, a between-sire analysis was considered, 
with a model (linear predictor) including the effects of sire, genotype of the dam, and their interaction. Due to consistent significance of the effects of sire and sire by dam genotype interaction, a series of within-sire analyses was performed for each SNP. The results are expressed in terms of test statistics $\left(\chi^{2}\right)$ values and associated $P$-values, as well as proportion (fertilization and survival rates) confidence intervals for each genotypic group of dams mated with each sire. These analyses were performed using the GENMOD procedure of SAS (SAS Institute, 2006).

\section{Experimental Cow Population}

Blood samples were obtained from the University of Wisconsin (UW) daughter design resource population (henceforth, the UW resource population). This population was originally created to search for QTL in association with susceptibility to paratuberculosis. For a detailed description of this population see Gonda et al. (2006) and Cobanoglu et al. (2006). Yield deviation and PTA data for daughters in the UW resource populations were obtained for milk, protein, and fat yields $(\mathrm{kg})$, protein and fat percentages, and SCS from the USDA Animal Improvement Programs Laboratory (Beltsville, $\mathrm{MD}$ ).

Genomic DNA was extracted from blood samples using GFX Genomic Blood DNA Purification Kit (Amersham Biosciences, Piscataway, NJ). All samples were genotyped for SNP12195 (exon 8) and SNP14217 (intron 9). Primers STATF1 and STATR1 were used to genotype SNP12195 (G/C) (Table 1). Amplification was performed in a $25-\mu \mathrm{L}$ reaction volume, which included 25 to $50 \mathrm{ng}$ of genomic DNA, $50 \mathrm{ng}$ of each primer, 200 $\mu M$ of each dNTP, $5.0 \mu \mathrm{L}$ of $5 \times$ PCR buffer (Promega), and 1.5 units of Taq DNA polymerase (Promega). The temperature cycles were as follows: $95^{\circ} \mathrm{C}$ for $5 \mathrm{~min}$, followed by 32 cycles of $94^{\circ} \mathrm{C}$ for $45 \mathrm{~s}$, touchdown annealing from $65-53^{\circ} \mathrm{C}$ for $45 \mathrm{~s}, 72^{\circ} \mathrm{C}$ for $45 \mathrm{~s}$, and a final extension at $72^{\circ} \mathrm{C}$ for $7 \mathrm{~min}$. Finally, SNP14217 (A/G) was genotyped by GeneSeek Inc. (Lincoln, NE).

\section{SNP Association Testing with Milk Production Traits}

Yield deviation data for each trait were analyzed using the following model:

$$
Y D_{i j k}=\mu+s_{i}+d_{i j} \tau+g_{k}+\varepsilon_{i j k}
$$

where $Y D_{i j k}$ represents the observation of daughter $\mathrm{j}$ of sire $i ; \mu$ is a general constant (intercept); $s_{i}$ is the fixed effect of sire i; $\tau$ is an effect associated with Mycobacterium paratuberculosis infection status; $d_{i j}$ is an disease indicator variable assuming the values 0 and 1 for noninfected and infected cows, respectively; $g_{k}$ is the effect of the genotypic group $\mathrm{k}$; and $\varepsilon_{i j}$ is a residual term. Mycobacterium paratuberculosis infection status was included in the model because the UW population was originally created to search for genetic markers associated with susceptibility to paratuberculosis. Specific contrasts of interest were used to estimate and to test for additive and dominance genetic effects as described in as in Khatib et al. (2007a).

In addition, PTA values of the cows were studied using an allele substitution model expressed as

$$
P T A_{i j k}=\mu+s_{i}+\beta x_{k}+\varepsilon_{i j k},
$$

where $P T A_{i j}$ is the observation of daughter $j$ of sire $i$; $\mu, s_{i}$ and $\varepsilon_{i j k}$ are defined as before; $\beta$ is the regression coefficient representing half of the allele substitution effect $(\alpha / 2)$; and $x_{k}$ is the number of copies $(0,1$, or 2) of the less-frequent allele at the marker locus on daughter $j$ of sire $i$. All analyses were implemented using the GLM procedure of SAS (SAS Institute, 2006).

\section{RESULTS}

\section{Identified Polymorphisms}

The search for SNP in 15,291 bp of genomic STAT5A revealed a total of 12 SNP, of which 11 SNP were identified in introns and 1 SNP (SNP12195) was identified in exon 8. Three SNP (SNP3117, SNP3419, and SNP3470) were identified in intron 4; and SNP12885, SNP12924, SNP13244, SNP13319, SNP13516, SNP13654, and SNP14217 were identified in intron 9. Only SNP15541 was identified in intron 12.

\section{Embryonic Survival and Fertilization Rates}

A total of 1,551 embryos were produced by IVF, and survival rate was measured at 7 of development. Table 2 has the survival rates of embryos and genotypes of dams and sires for the 12 SNP. For SNP3419, SNP13319, SNP13654, and SNP15541, no offspring or a small number of one of the homozygous genotypes was observed; therefore, these SNP were not further analyzed for the association with survival and fertilization rates. Figure 1A shows the $\chi^{2}$ results for the survival rate of embryos produced from the 3 sires. For sire 1, 7 SNP (SNP3117, SNP12195, SNP12885, SNP12924, SNP13244, SNP13516, and SNP14217) showed a highly significant association $(P<0.0001)$ with embryonic survival rate. For example, for SNP3117, the survival rate of embryos produced from the mating of sire 1 (AG) and genotype GG dams was $46 \%$ vs. 21 and $28 \%$ 
KHATIB ET AL.

Table 2. Embryonic survival and unfertilized ova (UFO) ratios and genotypes of cows and sires for the 12 single nucleotide polymorphisms (SNP) in the STAT5A gene

\begin{tabular}{|c|c|c|c|c|c|c|}
\hline $\mathrm{SNP} /$ sire & $\begin{array}{c}\text { Sire } \\
\text { genotype }\end{array}$ & $\begin{array}{c}\text { Dams' } \\
\text { genotypes }\end{array}$ & $\begin{array}{l}\text { Embryonic } \\
\text { survival rate }\end{array}$ & $\begin{array}{c}\text { Total } \\
\text { embryos }\end{array}$ & $\begin{array}{l}\mathrm{UFO} \\
\text { ratio }\end{array}$ & $\begin{array}{l}\text { Total embryos } \\
\text { and UFO }\end{array}$ \\
\hline \multicolumn{7}{|l|}{ SNP3117 } \\
\hline \multirow[t]{3}{*}{ Sire 1} & $\mathrm{AG}$ & $\mathrm{AA}$ & $0.28^{\mathrm{b}}$ & 188 & $0.41^{\mathrm{a}}$ & 317 \\
\hline & & $\mathrm{AG}$ & $0.21^{\mathrm{b}}$ & 95 & $0.38^{\mathrm{ab}}$ & 152 \\
\hline & & GG & $0.46^{\mathrm{a}}$ & 200 & $0.30^{\mathrm{b}}$ & 285 \\
\hline \multirow[t]{3}{*}{ Sire 2} & GG & AA & $0.42^{\mathrm{a}}$ & 124 & 0.35 & 192 \\
\hline & & AG & $0.27^{\mathrm{b}}$ & 139 & 0.37 & 219 \\
\hline & & GG & $0.43^{\mathrm{a}}$ & 75 & 0.31 & 109 \\
\hline \multirow[t]{3}{*}{ Sire 3} & GG & $\mathrm{AA}$ & $0.37^{\mathrm{ab}}$ & 188 & $0.36^{\mathrm{a}}$ & 293 \\
\hline & & $\mathrm{AG}$ & $0.42^{\mathrm{a}}$ & 281 & $0.30^{\mathrm{a}}$ & 399 \\
\hline & & GG & $0.32^{\mathrm{b}}$ & 248 & $0.20^{\mathrm{b}}$ & 309 \\
\hline \multicolumn{7}{|l|}{ SNP3419 } \\
\hline \multirow{3}{*}{ Sire 1} & CT & $\mathrm{CC}$ & $0.24^{\mathrm{b}}$ & 59 & 0.39 & 423 \\
\hline & & $\mathrm{CT}$ & $0.39^{\mathrm{a}}$ & 134 & 0.35 & 206 \\
\hline & & $\mathrm{TT}$ & $\mathrm{NA}^{1}$ & 0 & NA & 0 \\
\hline \multirow[t]{3}{*}{ Sire 2} & $\mathrm{TT}$ & $\mathrm{CC}$ & 0.38 & 165 & 0.36 & 257 \\
\hline & & $\mathrm{CT}$ & 0.34 & 167 & 0.35 & 257 \\
\hline & & $\mathrm{TT}$ & 0.46 & 13 & 0.24 & 17 \\
\hline \multirow[t]{3}{*}{ Sire 3} & $\mathrm{TT}$ & $\mathrm{CC}$ & $0.42^{\mathrm{a}}$ & 315 & $0.34^{\mathrm{a}}$ & 478 \\
\hline & & CT & $0.35^{\mathrm{ab}}$ & 384 & $0.21^{\mathrm{b}}$ & 485 \\
\hline & & $\mathrm{TT}$ & $0.24^{\mathrm{b}}$ & 33 & $0.39^{\mathrm{a}}$ & 54 \\
\hline \multicolumn{7}{|l|}{ SNP3470 } \\
\hline \multirow[t]{3}{*}{ Sire 1} & AG & $\mathrm{AA}$ & 0.25 & 198 & 0.41 & 335 \\
\hline & & $\mathrm{AG}$ & 0.31 & 139 & 0.33 & 207 \\
\hline & & GG & 0.41 & 56 & 0.36 & 87 \\
\hline \multirow[t]{3}{*}{ Sire 2} & GG & $\mathrm{AA}$ & 0.40 & 131 & $0.35^{\mathrm{a}}$ & 203 \\
\hline & & $\mathrm{AG}$ & 0.31 & 167 & $0.38^{\mathrm{a}}$ & 269 \\
\hline & & GG & 0.45 & 47 & $0.20^{\mathrm{b}}$ & 59 \\
\hline \multirow[t]{3}{*}{ Sire 3} & GG & AA & 0.39 & 248 & $0.36^{\mathrm{a}}$ & 388 \\
\hline & & $\mathrm{AG}$ & 0.38 & 435 & $0.21^{\mathrm{b}}$ & 554 \\
\hline & & GG & 0.27 & 49 & $0.35^{\mathrm{a}}$ & 75 \\
\hline \multicolumn{7}{|l|}{ SNP12195 } \\
\hline \multirow{3}{*}{ Sire 1} & GC & $\mathrm{CC}$ & $0.52^{\mathrm{a}}$ & 144 & 0.3 & 207 \\
\hline & & GC & $0.22^{\mathrm{b}}$ & 224 & 0.39 & 368 \\
\hline & & GG & $0.29^{b}$ & 136 & 0.39 & 223 \\
\hline \multirow[t]{3}{*}{ Sire 2} & $\mathrm{CC}$ & $\mathrm{CC}$ & 0.44 & 96 & 0.31 & 140 \\
\hline & & GC & 0.33 & 138 & 0.34 & 208 \\
\hline & & GG & 0.34 & 96 & 0.43 & 168 \\
\hline Sire 3 & GC & $\mathrm{CC}$ & 0.36 & 147 & 0.33 & 218 \\
\hline & & GC & 0.41 & 333 & 0.30 & 474 \\
\hline & & GG & 0.39 & 133 & 0.35 & 206 \\
\hline SNP12885 & & & & & & \\
\hline Sire 1 & $\mathrm{AC}$ & $\mathrm{AA}$ & $0.34^{\mathrm{b}}$ & 140 & $0.32^{\mathrm{ab}}$ & 205 \\
\hline & & $\mathrm{AC}$ & $0.19^{\mathrm{c}}$ & 170 & $0.41^{\mathrm{a}}$ & 287 \\
\hline & & $\mathrm{CC}$ & $0.55^{\mathrm{a}}$ & 91 & $0.28^{b}$ & 127 \\
\hline Sire 2 & $\mathrm{CC}$ & $\mathrm{AA}$ & $0.41^{\mathrm{a}}$ & 93 & $0.42^{\mathrm{a}}$ & 161 \\
\hline & & $\mathrm{AC}$ & $0.25^{b}$ & 92 & $0.25^{\mathrm{b}}$ & 123 \\
\hline & & $\mathrm{CC}$ & $0.39^{\mathrm{a}}$ & 83 & $0.31^{\mathrm{ab}}$ & 121 \\
\hline Sire 3 & $\mathrm{CC}$ & AA & 0.43 & 240 & 0.33 & 359 \\
\hline & & $\mathrm{AC}$ & 0.36 & 165 & 0.26 & 223 \\
\hline & & $\mathrm{CC}$ & 0.36 & 147 & 0.30 & 210 \\
\hline SNP12924 & & & & & & \\
\hline Sire 1 & $\mathrm{CT}$ & $\mathrm{CC}$ & $0.55^{\mathrm{a}}$ & 91 & $0.28^{\mathrm{b}}$ & 127 \\
\hline & & CT & $0.19^{c}$ & 170 & $0.41^{\mathrm{a}}$ & 287 \\
\hline & & TT & $0.34^{\mathrm{b}}$ & 140 & $0.32^{\mathrm{ab}}$ & 205 \\
\hline Sire 2 & $\mathrm{CC}$ & $\mathrm{CC}$ & $0.40^{\mathrm{a}}$ & 94 & 0.31 & 135 \\
\hline & & $\mathrm{CT}$ & $0.26^{\mathrm{b}}$ & 142 & 0.33 & 213 \\
\hline & & $\mathrm{TT}$ & $0.41^{\mathrm{a}}$ & 75 & 0.38 & 121 \\
\hline Sire 3 & $\mathrm{CC}$ & $\mathrm{CC}$ & 0.35 & 142 & 0.29 & 199 \\
\hline & & $\mathrm{CT}$ & 0.41 & 239 & 0.31 & 346 \\
\hline & & $\mathrm{TT}$ & 0.45 & 195 & 0.33 & 289 \\
\hline & & & & & & Continu \\
\hline
\end{tabular}


Table 2 (Continued). Embryonic survival and unfertilized ova (UFO) ratios and genotypes of cows and sires for the 12 single nucleotide polymorphisms (SNP) in the STAT5A gene

\begin{tabular}{|c|c|c|c|c|c|c|}
\hline SNP/sire & $\begin{array}{c}\text { Sire } \\
\text { genotype }\end{array}$ & $\begin{array}{c}\text { Dams' } \\
\text { genotypes }\end{array}$ & $\begin{array}{l}\text { Embryonic } \\
\text { survival rate }\end{array}$ & $\begin{array}{c}\text { Total } \\
\text { embryos }\end{array}$ & $\begin{array}{l}\mathrm{UFO} \\
\text { ratio }\end{array}$ & $\begin{array}{l}\text { Total embryos } \\
\text { and UFO }\end{array}$ \\
\hline \multicolumn{7}{|l|}{ SNP13244 } \\
\hline \multirow[t]{3}{*}{ Sire 1} & AG & AA & $0.33^{b}$ & 152 & $0.35^{\mathrm{ab}}$ & 234 \\
\hline & & AG & $0.19^{c}$ & 170 & $0.41^{\mathrm{a}}$ & 287 \\
\hline & & GG & $0.55^{\mathrm{a}}$ & 91 & $0.28^{\mathrm{b}}$ & 127 \\
\hline \multirow[t]{3}{*}{ Sire 2} & GG & $\mathrm{AA}$ & $0.43^{\mathrm{a}}$ & 87 & 0.41 & 147 \\
\hline & & AG & $0.26^{\mathrm{b}}$ & 142 & 0.33 & 213 \\
\hline & & GG & $0.40^{\mathrm{a}}$ & 105 & 0.31 & 153 \\
\hline \multirow[t]{3}{*}{ Sire 3} & GG & $\mathrm{AA}$ & $0.39^{\mathrm{ab}}$ & 187 & $0.31^{\mathrm{a}}$ & 272 \\
\hline & & $\mathrm{AG}$ & $0.43^{\mathrm{a}}$ & 260 & $0.30^{\mathrm{a}}$ & 272 \\
\hline & & GG & $0.30^{\mathrm{b}}$ & 276 & $0.21^{b}$ & 351 \\
\hline \multicolumn{7}{|l|}{ SNP13319 } \\
\hline \multirow[t]{3}{*}{ Sire 1} & GG & AA & $0.61^{\mathrm{a}}$ & 31 & $0.18^{\mathrm{b}}$ & 38 \\
\hline & & $\mathrm{AG}$ & $0.35^{\mathrm{b}}$ & 54 & $0.36^{\mathrm{ab}}$ & 85 \\
\hline & & GG & $0.29^{b}$ & 328 & $0.38^{\mathrm{a}}$ & 525 \\
\hline \multirow[t]{3}{*}{ Sire 2} & GG & $\mathrm{AA}$ & $\mathrm{NA}^{1}$ & 0 & NA & 0 \\
\hline & & $\mathrm{AG}$ & $0.23^{\mathrm{b}}$ & 52 & 0.30 & 74 \\
\hline & & GG & $0.37^{\mathrm{a}}$ & 282 & 0.36 & 439 \\
\hline \multirow[t]{3}{*}{ Sire 3} & GG & AA & 0.60 & 10 & 0.33 & 15 \\
\hline & & AG & 0.32 & 219 & 0.23 & 284 \\
\hline & & GG & 0.40 & 482 & 0.30 & 684 \\
\hline \multicolumn{7}{|l|}{ SNP13516 } \\
\hline \multirow{3}{*}{ Sire 1} & GT & GG & $0.53^{\mathrm{a}}$ & 143 & $0.29^{\mathrm{b}}$ & 200 \\
\hline & & GT & $0.22^{\mathrm{b}}$ & 208 & $0.40^{\mathrm{a}}$ & 345 \\
\hline & & $\mathrm{TT}$ & $0.30^{\mathrm{b}}$ & 142 & $0.35^{\mathrm{ab}}$ & 220 \\
\hline \multirow{3}{*}{ Sire 2} & GG & GG & 0.40 & 105 & 0.31 & 135 \\
\hline & & GT & 0.29 & 132 & 0.33 & 197 \\
\hline & & TT & 0.36 & 91 & 0.43 & 160 \\
\hline \multirow[t]{3}{*}{ Sire 3} & GG & GG & 0.37 & 127 & $0.31^{\mathrm{a}}$ & 184 \\
\hline & & GT & 0.42 & 271 & $0.31^{\mathrm{a}}$ & 395 \\
\hline & & $\mathrm{TT}$ & 0.36 & 270 & $0.21^{\mathrm{b}}$ & 342 \\
\hline \multicolumn{7}{|l|}{ SNP13654 } \\
\hline \multirow{3}{*}{ Sire 1} & AA & AA & $0.29^{b}$ & 371 & 0.38 & 594 \\
\hline & & $\mathrm{AG}$ & $0.41^{\mathrm{b}}$ & 113 & 0.31 & 163 \\
\hline & & GG & $0.83^{\mathrm{a}}$ & 18 & 0.22 & 23 \\
\hline \multirow[t]{3}{*}{ Sire 2} & AA & AA & 0.38 & 297 & 0.36 & 461 \\
\hline & & $\mathrm{AG}$ & 0.25 & 48 & 0.30 & 69 \\
\hline & & GG & NA & 0 & NA & 0 \\
\hline Sire 3 & AA & $\mathrm{AA}$ & $0.40^{\mathrm{b}}$ & 489 & 0.29 & 692 \\
\hline & & AG & $0.31^{\mathrm{b}}$ & 197 & 0.22 & 254 \\
\hline & & GG & $0.60^{\mathrm{a}}$ & 10 & 0.33 & 15 \\
\hline SNP14217 & & & & & & \\
\hline Sire 1 & $\mathrm{AG}$ & AA & $0.31^{\mathrm{b}}$ & 149 & 0.39 & 243 \\
\hline & & $\mathrm{AG}$ & $0.22^{\mathrm{b}}$ & 234 & 0.38 & 377 \\
\hline & & GG & $0.55^{\mathrm{a}}$ & 131 & 0.30 & 188 \\
\hline Sire 2 & GG & $\mathrm{AA}$ & $0.39^{\mathrm{a}}$ & 83 & 0.42 & 144 \\
\hline & & AG & $0.24^{\mathrm{b}}$ & 118 & 0.36 & 184 \\
\hline & & GG & $0.41^{\mathrm{a}}$ & 85 & 0.35 & 130 \\
\hline Sire 3 & GG & AA & 0.38 & 175 & 0.30 & 249 \\
\hline & & $\mathrm{AG}$ & 0.41 & 272 & 0.30 & 389 \\
\hline & & GG & 0.32 & 179 & 0.25 & 238 \\
\hline SNP15541 & & & & & & \\
\hline Sire 1 & $\mathrm{CC}$ & $\mathrm{CC}$ & $0.28^{\mathrm{c}}$ & 395 & 0.36 & 614 \\
\hline & & $\mathrm{CT}$ & $0.54^{\mathrm{b}}$ & 74 & 0.29 & 104 \\
\hline & & $\mathrm{TT}$ & $0.83^{\mathrm{a}}$ & 18 & 0.22 & 23 \\
\hline Sire 2 & $\mathrm{CC}$ & $\mathrm{CC}$ & 0.36 & 280 & 0.37 & 441 \\
\hline & & $\mathrm{CT}$ & 0.23 & 52 & 0.30 & 74 \\
\hline & & $\mathrm{TT}$ & NA & 0 & NA & 0 \\
\hline Sire 3 & $\mathrm{CC}$ & $\mathrm{CC}$ & $0.40^{\mathrm{b}}$ & 490 & 0.29 & 693 \\
\hline & & $\mathrm{CT}$ & $0.32^{\mathrm{c}}$ & 207 & 0.23 & 268 \\
\hline & & $\mathrm{TT}$ & $0.60^{\mathrm{a}}$ & 10 & 0.33 & 15 \\
\hline
\end{tabular}

${ }^{a-c}$ Values with the same superscript letters do not differ at the $5 \%$ significance level between cow genotype, for each sire.

${ }^{1} \mathrm{NA}=$ not applicable 

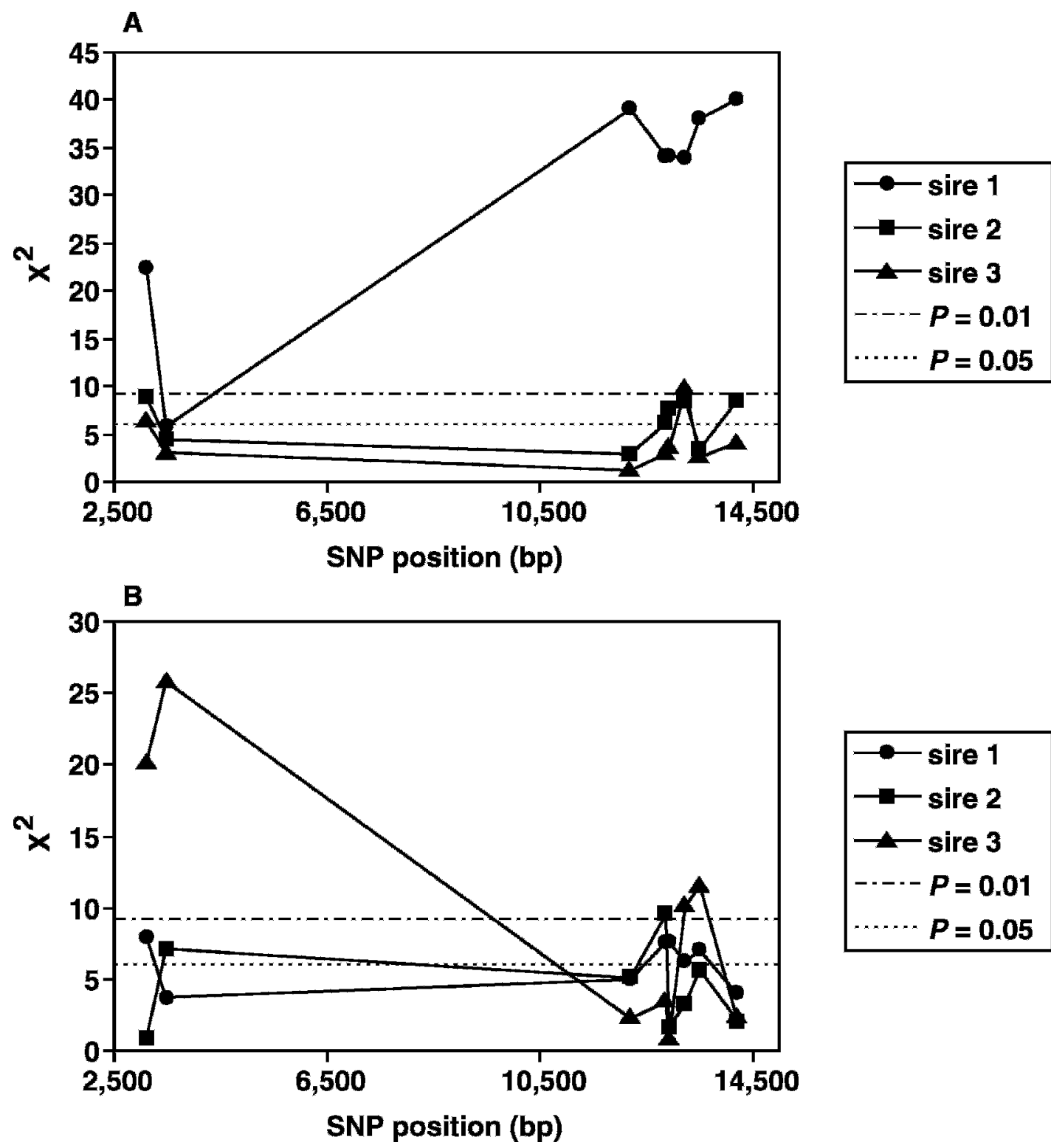

Figure 1. Analysis $\left(\chi^{2}\right)$ of A) embryonic survival rate and B) unfertilized ova for sires 1, 2, and 3 with single nucleotide polymorphisms (SNP) SNP3117, SNP3470, SNP12195, SNP12885, SNP12924, SNP13244, SNP13516, and SNP14217.

for embryos produced from AG and AA dams, respectively (Table 2). For sire 2, SNP3117, SNP12885, SNP12924, SNP13244, and SNP14217 showed significant association with survival rate. In contrast, for sire 3, only 2 SNP (SNP3117 and SNP13244) showed significant association with embryonic survival rate.

Figure 1B shows the $\chi^{2}$ results of UFO for the 8 SNP analyzed for the 3 sires. For sire 1, the rate of UFO was significantly associated $(P<0.05)$ with SNP3117, SNP12885, SNP12885, SNP12924, SNP13244, and SNP13516. For example, the UFO ratio for genotype
AA dams was 41 vs. $30 \%$ for genotype GG of SNP3117 (Table 2). Similarly, for SNP12924, the UFO ratio was $41 \%$ for the CT genotype vs. $28 \%$ for the CC genotype (Table 2). Also, genotypes of the exonic SNP12195 showed slight differences for UFO $(P=0.081)$. For sire 2 , significant associations with UFO were found for SNP3470 $(P<0.05)$ and SNP12885 $(P<0.01)$. For SNP12885, the UFO ratio for the AA genotype was $42 \%$ vs. $25 \%$ for the AC genotype (Table 2). For sire 3, a highly significant association with UFO was observed for SNP3117 and SNP3470 $(P<0.0001$, for both SNP). 
Table 3. SNP12195 genotypes of embryos produced from sires 1, 2, and 3

\begin{tabular}{|c|c|c|c|c|c|c|}
\hline \multirow[b]{2}{*}{ Sire } & \multirow[b]{2}{*}{ Genotype } & \multirow{2}{*}{$\begin{array}{c}\text { Dams' } \\
\text { genotypes }\end{array}$} & \multicolumn{3}{|c|}{ Embryo genotype } & \multirow{2}{*}{$\begin{array}{c}\chi^{2} \text { test } \\
(P \text {-value })\end{array}$} \\
\hline & & & $\mathrm{CC}$ & GC & GG & \\
\hline \multirow[t]{3}{*}{1} & \multirow[t]{3}{*}{ GC } & $\mathrm{CC}$ & 10 & 4 & - & \multirow{3}{*}{$\begin{array}{l}(0.108) \\
(0.011)\end{array}$} \\
\hline & & GG & - & 4 & 15 & \\
\hline & & GC & 1 & 2 & 2 & \\
\hline \multirow[t]{3}{*}{2} & \multirow[t]{3}{*}{$\mathrm{CC}$} & $\mathrm{CC}$ & 23 & - & - & \\
\hline & & GG & - & 7 & - & \\
\hline & & GC & 11 & 15 & - & $(0.432)$ \\
\hline \multirow[t]{3}{*}{3} & \multirow[t]{3}{*}{ GC } & $\mathrm{CC}$ & 8 & 1 & - & (0.019) \\
\hline & & GG & - & 14 & 2 & $(0.002)$ \\
\hline & & GC & 13 & 13 & 0 & $(0.001)$ \\
\hline
\end{tabular}

\section{Segregation Distortion of STAT5A Genotypes}

Table 3 shows genotypes of embryos and the parents for exonic SNP12195. To determine if there were genotype differences in preblastocyst stage embryonic losses, 145 of the surviving embryos were genotyped. For sire 1 (GC) when coupled with CC dams, 10 of the surviving embryos had the CC genotype and 4 had GC.

Genotyping of embryos produced from sire 1 and GG dams revealed a significant excess of GG vs. GC embryos $(P=0.011)$. For sire $3(\mathrm{GC})$, a significant segregation distortion was observed between offspring genotypes for all pairings (Table 3). Of particular interest was the observation of the decreased number of embryos with the GG genotype. Only 2 surviving GG embryos were produced from sire 3 and GG dams compared with 14 GC embryos $(P=0.002)$. Similarly, no GG genotypes were detected from the pairing of sire 3 with GC dams $(P=0.001)$. The coupling of sire 3 with $\mathrm{CC}$ dams resulted in an excess of CC vs. GC embryos $(P=0.019)$. sire 2 was homozygous (CC) for this SNP.

\section{Association with Milk Production Traits}

Genotyping results of 887 cows from the UW resource population revealed that the frequency of the $\mathrm{C}$ and $\mathrm{G}$ alleles at SNP12195 were 0.61 and 0.39 , respectively. Similarly, frequencies of the $\mathrm{A}$ and $\mathrm{G}$ alleles at SNP14217 were 0.39 and 0.61 , respectively. Table 4

Table 4. Estimates $( \pm \mathrm{SE})$ of the allele substitution effect of single nucleotide polymorphisms (SNP) 14217 and 12195 for production traits in the UW resource population

\begin{tabular}{lrr}
\hline Trait & \multicolumn{1}{c}{ SNP12195 } & \multicolumn{1}{c}{ SNP14217 } \\
\hline Fat yield $(\mathrm{kg})$ & $-1.75 \pm 2.48$ & $1.80 \pm 2.34$ \\
Fat $(\%)$ & $-0.0186 \pm 0.0090^{*}$ & $-0.0031 \pm 0.0084$ \\
Milk yield $(\mathrm{kg})$ & $82.8 \pm 64.6$ & $69.1 \pm 60.9$ \\
Protein yield $(\mathrm{kg})$ & $0.01 \pm 1.74$ & $1.20 \pm 1.64$ \\
Protein $(\%)$ & $-0.0101 \pm 0.0042^{*}$ & $-0.0035 \pm 0.0040$ \\
SCS & $0.0226 \pm 0.0130^{\dagger}$ & $0.0190 \pm 0.0124$ \\
\hline
\end{tabular}

$\dagger P<0.10 ; * P<0.05$.
Table 5. Estimates $( \pm \mathrm{SE})$ of the additive and dominance effects associated with SNP12195 in the UW resource population

\begin{tabular}{lccc}
\hline Trait & $\begin{array}{c}\text { Additive } \\
\text { effect }^{1}\end{array}$ & $\begin{array}{c}\text { Dominance } \\
\text { effect }\end{array}$ & $P$-value \\
\hline Fat yield (kg) & $-2.07 \pm 4.84$ & $2.41 \pm 5.23$ & 0.8658 \\
Fat (\%) & $-0.031 \pm 0.017 \dagger$ & $-0.013 \pm 0.019$ & 0.0641 \\
Milk yield (kg) & $161.7 \pm 129.1$ & $144.2 \pm 139.5$ & 0.1225 \\
Protein yield (kg) & $1.15 \pm 3.45$ & $2.48 \pm 3.72$ & 0.6547 \\
Protein (\%) & $-0.018 \pm 0.008^{*}$ & $-0.009 \pm 0.008$ & 0.0098 \\
SCS & $0.095 \pm 0.073$ & $-0.038 \pm 0.079$ & 0.4320 \\
\hline
\end{tabular}

${ }^{1}$ Additive effect relative to allele $\mathrm{G}$.

$\dagger P<0.10 ; * P<0.05$.

shows that allele G of SNP12195 was associated with a significant decrease in fat and protein percentages and with a less significant decrease in SCS. In contrast, SNP14217 was not significant for any of the examined traits. Estimates of dominant and additive effects of SNP12195 revealed that the GG genotype of this SNP was associated with a significant decrease in protein and fat percentages (Table 5). Single nucleotide polymorphism 14217 did not show significant association with any of the examined traits (data not shown).

\section{DISCUSSION}

In this study we report the association of the bovine STAT5A gene with fertilization success, embryonic survival, and milk composition in Holstein dairy cattle. The gene STAT5A is the first in a livestock species to be selected for association with quantitative traits based on a candidate pathway rather than position of the candidate gene. The death of embryos associated with STAT5A appears to occur much earlier than any other previously reported naturally occurring embryonic lethal polymorphism in mammals. The molecular mechanisms that cause this early embryonic death have not yet been identified. Nevertheless, there is firm evidence that mutations in STAT5A are associated with embryonic lethality in cattle.

First, a trial was conducted with in vitro-produced embryos. We evaluated the association between STAT5A polymorphisms and embryonic survival for more than 1,500 IVF embryos produced from 3 sires and 160 dams. Survival rate of embryos produced from sire 1 showed a highly significant association with 7 SNP including SNP12195. Similarly, 5 SNP showed significant association with survival rate of embryos produced from sire 2 . For both sires, the directions of the effects were consistent for all significant SNP. However, for sire 3, a significant association with embryonic survival rate was found for 2 SNP that showed the opposite effect to those found for sires 1 and 2 . These opposite effects are most likely due to linkage phase disequilib- 
rium between those SNP markers and the causative mutation for early embryonic death.

Second, we evaluated the association of fertilization rate of more than 2,300 oocytes with STAT5A polymorphisms. We found that the directions of the effects of 2 SNP (SNP3117 and SNP13244) were similar for all 3 sires, although for sire 2, the effects on fertilization rate did not reach significance. This result could be explained by a direct effect of STAT5A mutations on fertilization success. However, we cannot exclude the possibility that other SNP in the gene or in genes nearby are responsible for the observed effects. The most significant associations with fertilization rate were for sire 3. However, STAT5A in this sire had less significant effects on embryonic survival than sires 1 and 2 . These observations indicate that the factors affecting embryonic survival could differ from those affecting fertilization rate. Alternatively, the observed effects on embryonic survival and fertilization rate could be associated with a common mutation in linkage disequilibrium with the examined polymorphisms.

Third, segregation ratio distortion was observed for embryos genotyped for SNP12195. One hypothesis for this distortion is the prezygote selection of sire gametes for fertilization. Indeed, for sire 3 [heterozygous (GC) for SNP12195], the number of GG embryos produced from GG dams was much lower than expected, and no GG embryos were produced from GC dams. Furthermore, a highly significant decrease in fertilization rate was observed for this sire. It remains to be determined whether the genotype of sires has any effect on the observed segregation distortion. Several studies have shown that sperm genotype is an important factor in female meiosis and can lead to unequal allele frequencies (Pardo-Manuel de Villena and Sapienza, 2001). In our study, significant segregation distortion was observed for the 2 sires with genotype GC but not with the sire with genotype CC. However, this needs to be confirmed in a more-detailed analysis with a larger number of embryos.

The aforementioned results suggest that STAT5A is associated with 2 mechanisms by which it affects embryonic survival, although at present the relationship between these mechanisms is not clear. One is a prefertilization mechanism that involves sperm factors that cause low fertilization rate. This is supported by the results of sire 3 in which almost no GG embryos were produced. The second is a postfertilization mechanism that causes incompatibility between the male pronucleus and the oocyte that in turn leads to embryo death before the blastocyst stage. Incompatibility between male and female gametes has been suggested as a mechanism leading to embryo death in mice (Wakasugi, 2007). In DDK syndrome, mating of females from the
DDK inbred strain with males from other strains leads to arrest of cell division and proliferation and early embryonic death as a result of incompatibility between cytoplasmic factors of oocytes and spermatozoa factors (Wakasugi, 2007).

Genes causing embryonic death are difficult to identify (VanRaden and Miller, 2006). Nevertheless, 2 major genes affecting embryonic survival have been detected in cattle: deficiency of uridine monophosphate synthase (DUMPS) and complex vertebral malformation (CVM) (http://omia.angis.org.au/); these 2 genes are clearly distinct from STAT5A. First, DUMPS and CVM are relatively rare disorders, although they had a major impact in the dairy industry. Even at their greatest prevalence in the Holstein population, the deleterious alleles were never represented in more than $20 \%$ of animals (VanRaden and Miller, 2006). In contrast, our research indicates that the allele of the STAT5A gene associated with embryonic lethality is present in about $40 \%$ of the Holstein population. It also is present in other breeds of dairy cattle (unpublished data). Second, DUMPS and CVM cause pregnancy losses at later stages of pregnancy than STAT5A, which appears to cause very early pregnancy loss. Surprisingly, the early nature of the STAT5A lethality may have slowed the identification of this mutation and may have made it easier for the mutation to remain prevalent in the population. To illustrate, a pregnancy loss at 40 to $50 \mathrm{~d}$ would be readily identified by producers and would be extremely costly from both economic and reproductive efficiency viewpoints. In contrast, an early embryonic loss would be regarded as a failure to conceive and the cow would be rebred in the next estrous cycle, and, if successful, would result in a shorter calving interval than if the pregnancy loss were at a later stage of gestation.

In this study, STAT5A was chosen for association tests with milk production traits because of its role in mammary gland development. Brym et al. (2004) detected 1 SNP in intron 9 of STAT5A in association with milk production traits in 138 Jersey cows using single-strand conformation polymorphism. In contrast, in the current study, SNP14217 in intron 9 did not show any significant association with milk production or health traits. The association of allele G of SNP12195 with a decrease in both protein and fat percentages and with low survival rate is consistent with the genetic selection for milk yield in the last decades, which had a remarkable increase in productivity and a decrease in reproductive efficiency.

The STAT5A gene is a member of the signal transduction pathway of IFN- $\tau$ and PL. Genes of this pathway are involved in both initiation of pregnancy and of milk production and health traits. In previous studies, we have shown that several genes in this pathway are 
associated with milk production and health traits (Leonard et al., 2005; Cobanoglu et al., 2006; Khatib et al., 2007a,b). Thus, this pathway represents a unique system to investigate the complex relationship between milk production and pregnancy of cows at the molecular level. In this study, polymorphisms of STAT5A were found to be associated with both milk composition and infertility, although the relationship between these 2 phenotypes remains contentious. Washburn et al. (2002) analyzed the relationship of conception rate and milk production over a $>20$-yr time period (1976-1999) in dairy herds in the Southeastern United States. The conception rates clearly decreased from approximately $55 \%$ to about $35 \%$ during this period as milk production dramatically increased. Faust et al. (1988) showed a clear negative relationship between level of milk production and conception rate in primiparous Holstein dairy cattle. In contrast, Peters and Pursley (2002) reported that higher-producing cows had greater conception rates following a hormone injection series to synchronize estrus compared with lower-producing cows.

The gene STAT5A is the first found to be associated with both milk production and fertility. Of considerable interest was the observation that the $G$ allele of SNP12195 was associated with a significant decrease in milk protein and fat percentages and with low embryonic survival. Moreover, it would be of great importance to investigate the effects of additional genes in the signal transduction pathway of IFN- $\tau$ and PL to shed more light on the complex nature of the relationship between pregnancy and milk production. Although the causative mutation responsible for the observed effects has not been identified, we propose that the STAT5A gene can be used in genetic improvement programs to improve productive and reproductive efficiency in cattle.

\section{ACKNOWLEDGMENTS}

This study was supported by a start-up funding from the University of Wisconsin. We thank G. E. Shook for providing DNA samples from the UW resource population. We also thank Kent Weigel and Milo Wiltbank for their helpful discussions.

\section{REFERENCES}

Brym, P., S. Kaminski, and A. Rusc. 2004. New SSCP polymorphism within bovine STAT5A gene and its associations with milk performance traits in Black-and-White and Jersey cattle. J. Appl. Genet. 45:445-452.

Chen, X., U. Vinkemeier, Y. Zhao, D. Jeruzalmi, J. E. Darnell, and J. Kuriyan. 1998. Crystal structure of a tyrosine phosphorylated STAT-1 dimer bound to DNA. Cell 93:827-839.
Cobanoglu, O., I. Zaitoun, Y. M. Chang, G. E. Shook, and H. Khatib. 2006. Effects of the signal transducer and activator of transcription 1 (STAT1) gene on milk production traits in Holstein dairy cattle. J. Dairy Sci. 89:4433-4437.

Darnell, J. E. 1997. STATs and gene regulation. Science 277:16301635.

Faust, M. A., B. T. McDaniel, O. W. Robison, and J. H. Britt. 1988. Environmental and yield effects on reproduction in primiparous Holsteins. J. Dairy Sci. 71:3092-3099.

Gonda, M. G., Y. M. Chang, G. E. Shook, M. T. Collins, and B. W. Kirkpatrick. 2006. Genetic variation of Mycobacterium avium ssp. paratuberculosis infection in US Holsteins. J. Dairy Sci. 89:1804-1812.

Khatib, H., V. Schutzkus, Y. M. Chang, and G. J. M. Rosa. 2007a. Pattern of expression of the uterine milk protein gene and its association with productive life in dairy cattle. J. Dairy Sci. 90:2427-2433.

Khatib, H., I. Zaitoun, J. Wiebelhaus-Finger, Y. M. Chang, and G. J. M. Rosa. 2007b. The association of bovine PPARGC1A and OPN genes with milk composition in two independent Holstein cattle populations. J. Dairy Sci. 90:2966-2970.

Kisseleva, T., S. Bhattacharya, J. Braunstein, and C. W. Schindler. 2002. Signaling through the JAK/STAT pathway, recent advances and future challenges. Gene 285:1-24.

Leonard, S., H. Khatib, V. Schutzkus, Y. M. Chang, and C. Maltecca. 2005. Effects of the osteopontin gene variants on milk production traits in dairy cattle. J. Dairy Sci. 88:4083-4086.

McCullagh, P., and J. A. Nelder. 1989. Generalized Linear Models. 2nd ed. Chapman and Hall, London, UK.

Miyoshi, K., J. M. Shillingford, G. H. Smith, S. L. Grimm, K. U. Wagner, T. Oka, J. M. Rosen, G. W. Robinson, and L. Hennighausen. 2001. Signal transducer and activator of transcription (Stat) 5 controls the proliferation and differentiation of mammary alveolar epithelium. J. Cell Biol. 155:531-542.

Pardo-Manuel de Villena, F., and C. Sapienza. 2001. Nonrandom segregation during meiosis: The unfairness of females. Mamm. Genome 12:331-339.

Peters, M. W., and J. R. Pursley. 2002. Fertility of lactating dairy cows treated with Ovsynch after presynchronization injections of $\mathrm{PGF}_{2 \alpha}$ and GnRH. J. Dairy Sci. 85:2403-2406.

SAS Institute. 2006. SAS OnlineDoc. Version 9.1. SAS Institute Inc., Cary, NC.

Spencer, T. E., and F. W. Bazer. 2002. Biology of progesterone action during pregnancy recognition and maintenance of pregnancy. Front. Biosci. 1:d1879-d1898.

Spencer, T. E., and F. W. Bazer. 2004. Conceptus signals for establishment and maintenance of pregnancy. Reprod. Biol. Endocrinol. $2: 49$.

Stewart, M. D., Y. Choi, G. A. Johnson, L. Y. Yu-Lee, F. W. Bazer, and T. E. Spencer. 2002. Roles of Stat1, Stat2, and interferon regulatory factor-9 (IRF-9) in interferon tau regulation of IRF-1. Biol. Reprod. 66:393-400.

Teglund, S., C. McKay, E. Schuetz, J. M. van Deursen, D. Stravopodis, D. Wang, M. Brown, S. Bodner, G. Grosveld, and J. N. Thle. 1998. Stat5a and Stat5b proteins have essential and nonessential, or redundant, roles in cytokine responses. Cell 93:841-850.

VanRaden, P. M., and R. H. Miller. 2006. Effects of nonadditive genetic interactions, inbreeding, and recessive defects on embryo and fetal loss by seventy days. J. Dairy Sci. 89:2716-2721.

Wakasugi, N. 2007. Embryologic, cytobiologic and genetic interpretations of DDK syndrome in mice. Dev. Growth Differ. 49:555-559.

Washburn, S. P., W. J. Silvia, C. H. Brown, B. T. McDaniel, and A. J. McAllister. 2002. Trends in reproductive performance in southeastern Holstein and Jersey DHI herds. J. Dairy Sci. 85:244-251.

Watson, C. J. 2001. Stat transcription factors in mammary gland development and tumorigenesis. J. Mammary Gland Biol. Neoplasia 6:115-127. 